\title{
Does erosive tooth wear affect the oral health-related quality of life of pre- school children?
}

\author{
Os desgastes dentários erosivos afetam a qualidade de vida relacionada à saúde bucal em pré-escolares?
}

\author{
Gustavo TELLO' \\ Luciana Butini OLIVEIRA² \\ Christiana MURAKAMI3 \\ Gabriela Cunha BONINI² \\ Jenny $\mathrm{ABANTO}^{3}$ \\ Marcelo BÖNECKER ${ }^{4}$
}

\section{ABSTRACT}

\section{Objective}

The aim of this study was to investigate the impact of erosive tooth wear on the Oral Health-Related Quality of life (OHRQoL) of preschool children.

\section{Methods}

Dental examinations were conducted on 815 children aged 3-4 years during the Children's Vaccination National Day when their parents were also invited to answer the Brazilian Early Childhood Oral Health Impact Scale (B-ECOHIS). ETW prevalence and severity were measured using a modified version of the O'Brien index (1994). Data collected included socioeconomic factors and child's variables. OHRQoL was measured through B-ECOHIS domains and total score. Poisson regression was used to associate ETW to the outcome and this association was adjusted for dental caries and dental trauma.

\section{Results}

The proportion of children who had at least 1 ETW tooth was 51.2\%. Most erosive lesions were confined to enamel (42.7\%). The multivariate adjusted model showed that child's age (children aged 4year-old) was associated to a negative impact on the symptom domain (RR=1.70; $p=0.010)$, functional limitation domain $(R R=1.85 ; p=0.005)$ and total $B$-ECOHIS score $(R R=1.63 ; p=0.006)$. Families with 2 or more children in the house have a negative impact on the self-image/social interaction domain (RR=5.41; $p=0.043)$. ETW was not associated to total $B$-ECOHIS scores $(R R=0.79 ; p=0.163)$ and individual domains.

\section{Conclusion}

Erosive tooth wear does not affect the OHRQoL in this sample of preschool children.

Indexing terms: Oral health-related quality of life. Prevalence. Tooth erosion.

\section{RESUMO}

\section{Objetivo}

O objetivo deste estudo foi investigar o impacto das lesões de desgaste dentário erosivo na qualidade de vida relacionada à saúde bucal (QVRSB) de pré-escolares.

\section{Métodos}

Exames clínicos foram conduzidos em 815 crianças de 3 e 4 anos de idade durante a Campanha Nacional de Multivacinação Infantil. Os pais ou responsáveis foram convidados a responderam a versão brasileira do Early Childhood Oral Health Impact Scale (B-ECOHIS). A prevalência e a gravidade das lesões de desgastes dentários erosivos foram avaliadas de acordo com o índice de O'Brien (1994). Também foram coletados dados socioeconômicos e variáveis da criança. A QVRSB foi mensurada por meio dos domínios e escore total do B-ECOHIS. A análise de regressão de Poisson foi adotada para associar as lesões de desgaste dentário erosivo ao desfecho e ajustada para cárie dentária e lesões dentárias traumáticas.

\section{Resultados}

A proporção de crianças que apresentavam pelo menos 1 dente apresentando desgaste dentário erosivo foi 51,2\%. A maioria das lesões de desgaste dentário erosivo estava confinada ao esmalte (42,7\%). A análise ajustada multivariada revelou que apenas que a idade (crianças de 4 anos) foi associada a um impacto negativo nos domínios de sintomas ( $R R=1,70 ; p=0,010)$, limitação funcional $(R R=1,85 ; p=0,005)$ e escore total do $B-E C O H I S ~(R R=1,63 ; p=0,006)$. Famílias com 2 ou mais filhos tiveram um impacto negativo nos dominíos de autoestima e interação social $(R R=5,41 ; p=0,043)$. As lesões de desgaste dentário erosivo não foram associadas ao escore total de $B-E C O H I S(R R=0,79 ; p=0,163)$ e domínios individuais.

\section{Conclusão}

As lesões de desgaste dentário erosivo não afetaram a qualidade de vida de pré-escolares da amostra estudada.

Termos de indexação: Qualidade de vida relacionada à saúde bucal. Prevalência. Erosão dentária.

\footnotetext{
${ }^{1}$ Universidad Central del Ecuador, Departmento de Odontopediatria. Av. Universitaria, Quito 170129, Quito, Equador. Correspondência para / Correspondence to: G TELLO. E-mail: < gustelme@hotmail.com>.

${ }^{2}$ Faculdade São Leopoldo Mandic, Divisão de Odontopediatria, Campinas, SP, Brasil.

${ }^{3}$ Universidade de São Paulo, Faculdade de Odontologia, Departamento de Odontopediatria e Ortodontia, São Paulo, SP, Brasil.

${ }^{4}$ Universidade de São Paulo, Faculdade de Saúde Pública, Departamento de Epidemiologia, São Paulo, SP, Brasil.
} 


\section{INTRODUCTION}

Erosive tooth wear (ETW) is multifactorial condition often described solely as a surface phenomenon. However, it shows dissolution of mineral within the softened layer-beneath the surface. Erosive damage to the teeth may compromise the patient's dentition for their entire lifetime and may require repeated and expensive restorations ${ }^{1}$. Recent reports have demonstrated that the prevalence of ETW has increased in preschool ${ }^{2-3}$ and schoolchildren ${ }^{3-4}$. Yet, a recent systematic review has shown that the prevalence of ETW increases with the age $^{5}$. ETW in children is generally associated to frequent consumption of soft drinks and fresh/juices ${ }^{6-8}$ and gastroesophageal reflux ${ }^{6}$.

It is crucial to investigate the presence of ETW in the primary dentition due to cumulative nature of the erosive process, when lesions are not diagnosed early and the habits causing excessive wear are not modified, triggering possible severe loss of dental structure development. As the prevalence of ETW appears to be increasing in this population ${ }^{2-4}$, there has been a growing concern among dental practitioners and researchers alike on this matter.

There is clear evidence of an association between socioeconomic factors and dental caries in preschool children, while there is conflicting evidence whether these factors are related to ETW occurrence ${ }^{9-11}$. It has been shown that socioeconomic disparities directly influence the impact that dental diseases have on the child's OHRQoL ${ }^{12}$. Yet, the magnitude of this factor related to ETW remains unclear.

Even though most epidemiological studies have reported a high ETW prevalence in preschool children none of them have investigated its impact on the preschool children's oral health-related quality of life (OHRQoL). Only a Brazilian study has assessed the impact of tooth erosion on OHRQoL in children aged 11-14-years ${ }^{13}$. It is essential to investigate this impact in different age groups. Therefore, the main aim of this study was to assess the impact of ETW on preschool children' OHRQoL in a Brazilian population-based sample. In addition, confounding effects of socioeconomic factors have been assessed in the present study.

\section{METHODS}

A cross-sectional survey was performed on children aged 3-4 years, of both genders, living in Diadema, State of São Paulo, Brazil. It was estimated that a minimum sample size of 624 children was required to achieve a level of accuracy with a standard error of $2 \%$ or less ${ }^{14}$. The 95\% confidence interval level and a prevalence of EWT of $51.6 \%$ were used for the calculation. This prevalence was obtained in a previous survey carried out in Diadema ${ }^{6}$. To cover non-response, the sample was increased by $20 \%$ to 748 children and their parents/caregivers. As the data collection in the present epidemiological study assessed several outcomes, we calculated the sample size for each outcome and we used the highest value for all the outcomes. For this reason in this study our final sample size was 815 children and parents, however this small difference did not compromise our results. It is important to mention that all the sample size calculations used the same parameters except for the prevalence, which was different according to the interest outcome.

Participants were systematical selected from all children attending a statutory National Day of Children's Vaccination. The city of Diadema, which has been administratively divided into 19 regions, also has only 19 health centers, all public and equipped with dental chairs and facilities that could be used for a dental examination Population from low socioeconomic backgrounds attend these centers, which were all used in this study. A sampling quota was selected from all children attending each of the 19 health centers. Quota sampling was adopted since the population was equally distributed in all regions. The Human Development Index of Diadema is 0.757.

Most 3 and 4 year-olds Brazilian do not attend schools ${ }^{15}$ whereas the vaccination programme in Diadema consistently had uptake rates of above $94 \%$ of preschool children ${ }^{15}$. Each fifth child in the queue for vaccination was invited to participate. If parents did not agree to participate, the next child in the queue was selected. This systematical process was the same for all of the 19 health centres. Children with no systemic and / or neurological diseases as well those parents fluent in Brazilian Portuguese, were also included. To avoid possible biases, relatives and children living in the same household were excluded from the study.

Nineteen previously calibrated examiners from each health centre in the city, all post-graduate students of Pediatric Dentistry who had had previous experience in previous epidemiological surveys, individually carried out the child's clinical oral examinations. The examiners underwent 2 training sessions and calibration exercises 
for ETW, with an interval of 1 week between sessions to assess intra and interexaminer reliability. These sessions were carried out by a benchmark examiner experienced in ETW diagnosis using the modified O'Brien index ${ }^{16}$. Kappa coefficients for ETW were obtained using a sample of 20 clinical slides and 20 extracted human primary teeth from a Tooth Bank, which represented all possible ETW classification scores. For ETW, weighted intra- and interexaminer kappa values for lesion depth were 0.85 and 0.82 , respectively, and for lesion area they were 0.79 and 0.73 .

Children were seated on a dental chair and examined under a standard conventional light. Before the clinical examination, wet gauze pads were used to clean the tooth surfaces of loose debris. Visual examination with a plane dental mirror was conducted and no dental probing was used. Data collection included oral examinations for ETW, dental caries and traumatic dental injuries.

A modified version of the $O^{\prime} B$ rien index ${ }^{16}$ was used for ETW. The criteria of the modified O'Brien index ${ }^{16}$ for lesion depth and area are described in Table 1. For the evaluation of erosive lesion depth, this index attributes the scores 1, 2, and 3, respectively, for lesions into enamel, dentin, and close proximity pulp. For the evaluation of lesions area, the O'Brien index attributes the scores of 1 , 2 and 3, respectively, to lesions involving one third, two thirds, or more than two thirds of the area of the surface being examined.

Table 1. Diagnosis criteria for ETW scores of modified O'Brien index ${ }^{16}$.

\begin{tabular}{cccc}
\hline Score & Depth & Score & Area \\
\hline 0 & Healthy & 0 & $\begin{array}{c}\text { Healthy } \\
\text { Involving up } \\
\text { to one third of } \\
\text { surface } \\
\text { Involving up to } \\
\text { two thirds of } \\
\text { surface } \\
\text { Involving over } \\
\text { two thirds of } \\
\text { surface } \\
\text { E }\end{array}$ \\
\hline Dentine lesion & 2 & 3 & $\begin{array}{c}\text { Assessment not } \\
\text { possible }\end{array}$ \\
\hline
\end{tabular}

For criteria of both lesion depth and area, score 0 refers to a sound dental surface. However, score 9, which refers to cases where the assessment could not be made.
When assessing lesion depth, a score of 9 was given only when the tooth presented an extensive restoration or carious lesion that covered the entire surface or when the tooth was missing. Otherwise, erosion depth was scored, even in cases where only a small part of the surface that was not covered by a restoration or carious lesion was present. On the other hand, for the assessment of the lesion area, even small carious lesions or restorations impaired the assessment. In such cases, a score of 9 was recorded. Children who had score 9 in one or more teeth were not excluded from the sample. This methodology was used in a previous study carried out by the same authors ${ }^{6}$.

The ETW prevalence was dichotomized; children were considered to either have or not at least 1 tooth with ETW score 1 or above and according to its severity. The palatal surface of upper incisors ${ }^{17-21}$ and the occlusal surface of lower molars $22-23$ are the tooth sites most commonly affected by ETW. Thus, those teeth and surfaces were used as index teeth for assessment in the present and in previous studies. Since wear on incisal surfaces commonly present a great attrition component, these surfaces were not examined.

Dental caries was assessed according to the World Health Organization $(\mathrm{WHO})^{24}$ criteria and calculated in terms of primary teeth that were decayed, indicated for extraction due to caries, or filled (dmf-t), and then children were then classified by dental caries experience ${ }^{25}$. Traumatic dental injuries (TDI) in anterior upper primary incisors were classified according to Glendor et al. ${ }^{26}$ modified for epidemiological studies. The data on dental caries and TDI were used in this paper to adjust the results in the regression analyses. This is because the negative effect of and caries and TDI on OHRQoL in preschool children has been reported and proved in other studies ${ }^{12,27-28}$.

On the day of the National Day of Children's Vaccination, one of the parents or guardians was invited to answer two structured questionnaires in a face-to-face interview: one on socioeconomic conditions and child's variables and another on the child's OHRQoL. Interviews were carried out by nineteen dental assistants who were trained in the reading and intonation of each question and option of responses to the OHRQoL instrument. The data collected on socieconomic factors included family income, family structure, parental levels of education, household conditions and overcrowding. Family income was calculated by adding up the monthly wages of its 
active members and dividing it by the current Brazilian Minimum Wage (1 BMW $=\$ 300.00$ per month). Parent's level of education was measured in numbers of years at school. Family structure was assessed by a variable describing whether the children lived in a two-parent family or in some other situation.

The Brazilian version of the ECOHIS (B-ECOHIS) ${ }^{29}$ was applied to investigate the children's OHRQoL. It contains 13 questions corresponding to four descriptive domains for items included in the child impact section: symptoms - 01 item; function - 04 items; psychological 02 items; self-image/social interaction - 02 items; and two domains for the family impact section: parent's distress - 02 items and family function - 02 items. Response categories for the ECOHIS were coded: $0=$ never; $1=$ hardly ever; 2 = occasionally; $3=$ often; 4 = very often; $5=$ don't know. The total ECOHIS scores and scores for individual domains were calculated as a simple sum of the code response. Higher scores indicate a more negative impact on the OHRQoL.

Statistical analyses were performed using STATA software 9.0 (Stata Corp., College Station, TX, USA). Initially, descriptive analysis assessed measures of central tendency (means, standard deviations and range observed) of total and individual domain scores of the B-ECOHIS.

Poisson Regression with robust variance was performed to associate the individual domains and total B-ECOHIS scores to ETW, socioeconomic factors and child's variables. The variables were adjusted for caries and trauma. Univariate Poisson Regression analysis was performed to select variables with a P-value $<0.20$ to enter the model. Then, explanatory variables selected were tested in the multivariate adjusted model and retained only if they had a P-value $\leq 0.05$. In this analysis, the outcome was employed as a count outcome, rate ratios (RR) and 95\% confidence intervals $(95 \% \mathrm{Cl}$ ) were calculated.

\section{RESULTS}

A total of 815 children and their parents participated in this study. The uptake rate for the vaccination campaign in Diadema was $100 \%$ and most parents agreed to their child's participation, yielding a response rate above $80 \%$.

All parents interviewed have completed the B-ECOHIS questionnaire. Most of the questionnaires were answered by mothers (89.5\%). Table 2 shows the mean, standard deviation and the range observed for the total B-ECOHIS score and for individual domains. All questionnaires were fully completed without any missing data and there were also no "Don't know" responses. No ceiling effects were observed for either of the two sections, i.e., scores of 36 and 16 on the child and family impact sections, respectively. Overall, $67.9 \%$ of the parents reported no impacts, that is, score of 0 (floor effects) on the total B-ECOHIS-score. The maximum highest score of impacts reported was 33 on the total B-ECOHIS of the sample. The total mean (standard deviation) B-ECOHIS score was 1.55 (3.44).

Table 2. Descriptive distribution of individual domains and total scores B-ECOHIS

\begin{tabular}{lcccc}
\hline & Minimum & Maximum & Means & $\begin{array}{c}\text { Standard } \\
\text { Deviations }\end{array}$ \\
\hline SD & 0 & 5 & 0.30 & 0.754 \\
FD & 0 & 13 & 0.56 & 1.481 \\
PD & 0 & 8 & 0.25 & 0.855 \\
SSD & 0 & 5 & 0.05 & 0.393 \\
PDD & 0 & 6 & 0.25 & 0.894 \\
FFD & 0 & 5 & 0.13 & 0.557 \\
Total scores & 0 & 33 & 1.55 & 3.442 \\
B-ECOHIS & 0 & & & \\
\hline
\end{tabular}

SD: symptoms domain; FD: function domain; PD: psychological domain; SSD: self-image/social interaction domain; PDD: parental distress domain; FFD: family function domain.

The proportion of children who had at least 1 tooth with ETW was $51.3 \%$. The proportion of children who had only enamel lesions was $42.7 \%$ and $8.5 \%$ presented erosive lesions in dentin and proximity to pulp (Table 3). There was no significant difference in the prevalence of ETW between boys and girls ( $p=0.442$, Chi-square test). Table 3 also contains the unadjusted assessment of socioeconomic factors and child's variables associated to overall and domain-specific B-ECOHIS scores. This univariate analysis showed that the age of the child, the severity and area affected of ETW, mother's education, family income and the number of children in the house were correlated to some domains and total B-ECOHIS scores $(p<0.05)$.

The final multivariate adjusted model showed that children aged 4-years-old were associated to a negative impact on the symptoms domain ( $R R=1.70 ; p=0.010)$, functional limitation domain ( $R R=1.85 ; p=0.005)$ and total $\mathrm{B}$-ECOHIS score ( $R R=1.63 ; \mathrm{p}=0.006$ ). Moreover, families with 2 or more children in the house have a negative impact on the self-image/social interaction domain ( $R R=5.41$; $\mathrm{p}=0.043)$. ETW was not associated to total B-ECOHIS scores $(R R=0.79 ; p=0.163)$ and individual domains (Table 4). 
Table 3. Descriptive distribution of individual domains and total scores B-ECOHIS.

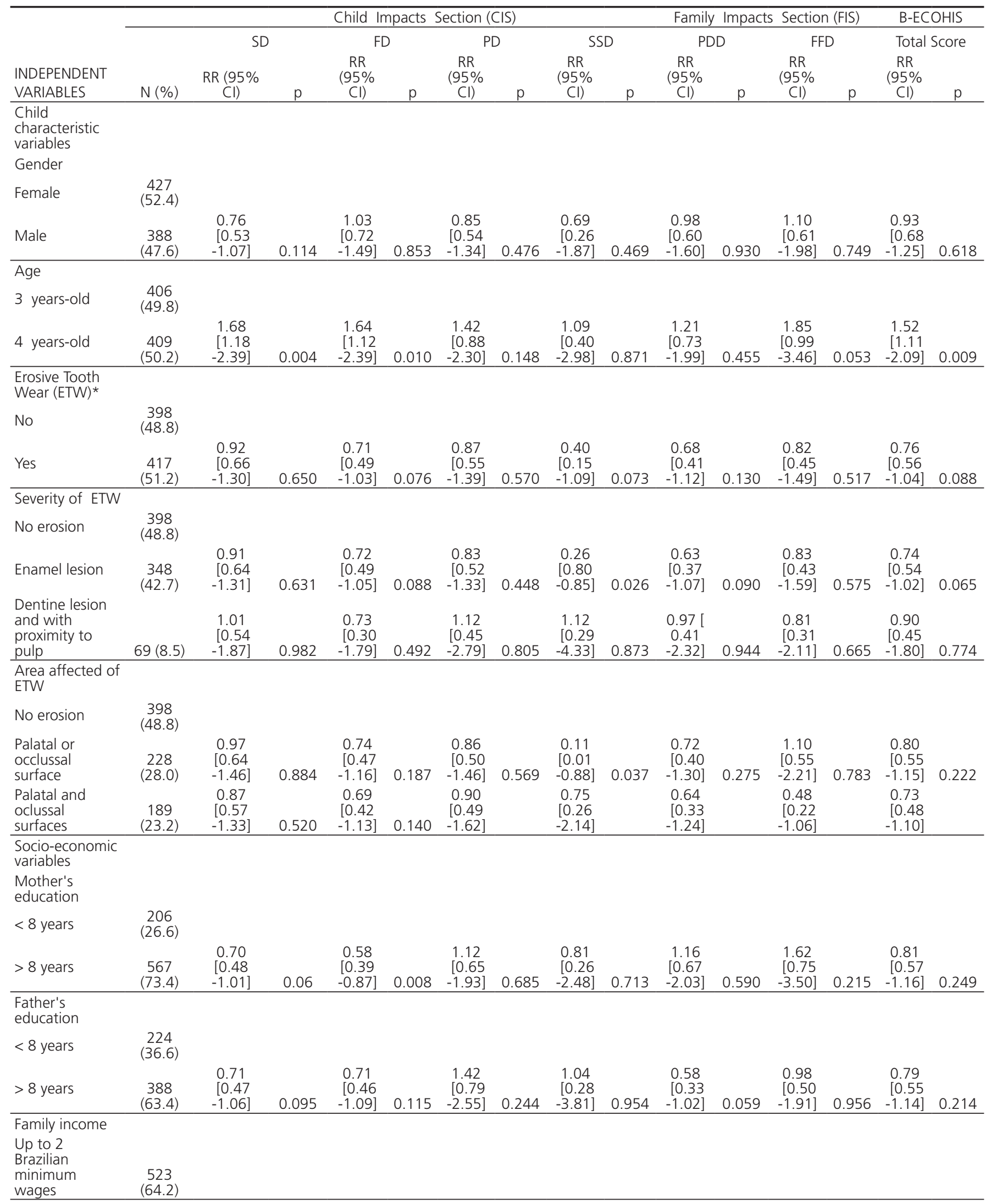




\begin{tabular}{|c|c|c|c|c|c|c|c|c|c|c|c|c|c|c|c|}
\hline $\begin{array}{l}>2 \text { Brazilian } \\
\text { minimum } \\
\text { wages }\end{array}$ & $\begin{array}{c}292 \\
(35.8) \\
\end{array}$ & $\begin{array}{c}0.84 \\
{[0.58} \\
-1.21] \\
\end{array}$ & 0.344 & $\begin{array}{c}0.69 \\
{[0.47} \\
-1.02] \\
\end{array}$ & 0.065 & $\begin{array}{r}0.58 \\
{[0.35} \\
-0.97] \\
\end{array}$ & 0.037 & $\begin{array}{c}0.53 \\
{[0.17} \\
-1.66] \\
\end{array}$ & 0.274 & $\begin{array}{c}0.82 \\
{[0.48} \\
-1.38] \\
\end{array}$ & 0.456 & $\begin{array}{c}1.27 \\
{[0.71} \\
-2.29] \\
\end{array}$ & 0.424 & $\begin{array}{c}0.75 \\
{[0.55} \\
-1.03] \\
\end{array}$ & 0.079 \\
\hline $\begin{array}{l}\text { House } \\
\text { overcrowding } \\
\text { Up to } 1 \text { person } \\
\text { per room }\end{array}$ & \multicolumn{2}{|c|}{$\begin{array}{l}\text { House } \\
\text { overcrowding }\end{array}$} & & & & & & & & & & & & & \\
\hline $\begin{array}{l}>1 \text { person per } \\
\text { room }\end{array}$ & $\begin{array}{c}333 \\
(42.7) \\
\end{array}$ & $\begin{array}{r}1.48 \\
{[1.05} \\
-2.10] \\
\end{array}$ & 0.026 & $\begin{array}{r}1.29 \\
{[0.89} \\
-1.87] \\
\end{array}$ & 0.180 & $\begin{array}{r}1.38 \\
{[0.86} \\
-2.23] \\
\end{array}$ & 0.185 & $\begin{array}{r}1.34 \\
{[0.48} \\
-3.75] \\
\end{array}$ & 0.578 & $\begin{array}{r}1.32 \\
{[0.79} \\
-2.21] \\
\end{array}$ & 0.282 & $\begin{array}{r}0.78 \\
{[0.41} \\
-1.47] \\
\end{array}$ & 0.445 & $\begin{array}{r}1.30 \\
{[0.95} \\
-1.78] \\
\end{array}$ & 0.105 \\
\hline \multicolumn{16}{|l|}{$\begin{array}{l}\text { House } \\
\text { ownership }\end{array}$} \\
\hline Rented house & $\begin{array}{c}432 \\
(56.2)\end{array}$ & $\begin{array}{c}0.71 \\
{[0.50} \\
-1.01]\end{array}$ & 0.051 & $\begin{array}{c}0.76 \\
{[0.52} \\
-1.10] \\
\end{array}$ & 0.141 & $\begin{array}{c}0.83 \\
{[0.52} \\
-1.33] \\
\end{array}$ & 0.448 & $\begin{array}{c}0.39 \\
{[0.13} \\
-1.18] \\
\end{array}$ & 0.096 & $\begin{array}{c}0.79 \\
{[0.48} \\
-1.31] \\
\end{array}$ & 0.369 & $\begin{array}{c}0.73 \\
{[0.40} \\
-1.33] \\
\end{array}$ & 0.307 & $\begin{array}{r}0.75 \\
{[0.55} \\
-1.02] \\
\end{array}$ & 0.064 \\
\hline \multicolumn{16}{|l|}{$\begin{array}{l}\text { Number of } \\
\text { children }\end{array}$} \\
\hline
\end{tabular}

$\mathrm{RR}=$ Rate ratio; $\mathrm{SD}=$ Symptom domain; $\mathrm{FD}=$ Psychological domain; SSD= Self-image/social interaction domain; $P D D=P a r e n t$ distress domain; $\mathrm{FFD}=$ Family function domain. * Results also adjusted for dental caries and dental trauma.

Table 4. Adjusted assessment of socioeconomic and child variables associated with overall and domain-specific B-ECOHIS scores.

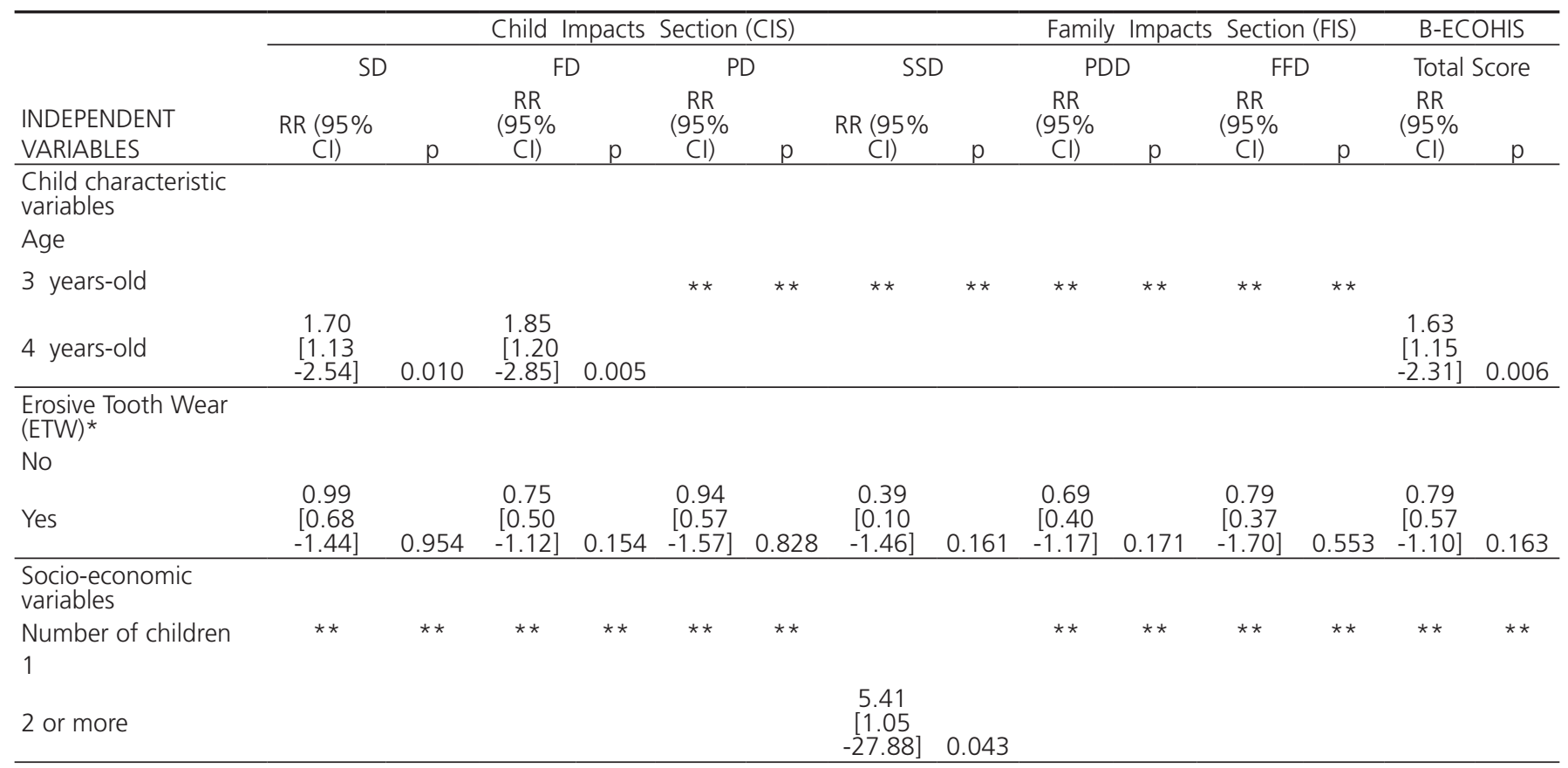

* Results also adjusted for dental caries and dental trauma. ** Variables not included in the final multiple model after the adjustment. RR $=$ Rate ratio; SD= Symptom domain; FD= Psychological domain; SSD= Self-image/social interaction domain; PDD= Parent distress domain; FFD= Family function domain.

\section{DISCUSSION}

The oral health problems affecting Brazilian children have received special attention in epidemiology and contemporary dentistry. A healthy smile has considerable bearing on social interaction, which plays an important role in how children are seen, felt and perceived by others ${ }^{30}$. ETW was diagnosed in $51.2 \%$ of the children in this study. There are few epidemiological investigations on the prevalence and severity of ETW in preschool children ${ }^{3-4,6,31}$. Prevalence rates varied from $0.6 \% 26$ to $65 \% 32$. Comparisons among studies should 
be interpreted with caution due to the lack of uniformity in recorded methods. The differences in prevalence are mainly due to indexes adopted among studies or dietary habits between countries and regions ${ }^{33}$.

The prevalence of ETW in preschool children found in the present study was high. A plausible explanation for this is that the consumption of soft drinks in Brazil is high among young children ${ }^{34}$. A National Survey in Brazil found consumption of soft drinks in $11.6 \%$ of children aged 9-12 months ${ }^{35}$. The majority reports have highlighted the association between ETW, dietary factors and high consumption of acid beverage intake $e^{4,6-8}$.

The ETW diagnosis could be difficult to be performed. However, it was possible to achieve good inter and intra-examiner Cohen's kappa agreement values when using the O'Brien index during the training and calibration exercises. Tooth wear index presents important limitations for measuring the prevalence of tooth erosion, since it is not specific to detect this condition, measuring, consequently, abrasion and attrition. However, the decision whether to use a modified version of the O'Brien index ${ }^{16}$ was based on the fact that it possesses most of the ideal characteristics of an index, and also because it was the index used in a 2008 study conducted by $u^{6}{ }^{6}$. The $\mathrm{O}^{\prime}$ Brien index is one of the most commonly used dental erosion index in prevalence studies involving preschool children and has been shown to have good reproducibility. As in our previous study, it was possible to achieve good inter and intra-examiner Cohen's kappa agreement values when using this index during the training and calibration exercises.

In general, ETW does not impact on the OHRQoL in this sample of preschool children. Even tough significant differences were observed in overall and domain-specific B-ECOHIS scores between children with and without ETW in the unadjusted analysis, this result was not confirmed in our multivariate adjusted final model. It has been suggested that severe ETW could affect masticatory capacity, phonetics, discomfort and pain symtoms and altered aesthetics ${ }^{10}$. However, data regarding the relationship between ETW and OHRQoL are scarce. In Brazil, a study carried out in schoolchildren shows that ETW lesions at low level of prevalence and severity have not presented an impact on the child's perception of oral health and daily performance ${ }^{11}$. According to these authors children with severe ETW have low levels of severity, which probably do not cause pain or any other psychosocial discomfort for them. Further studies are needed in order to confirm this finding and to investigate whether the presence of high levels of ETW severity has an impact on OHRQoL.

In this study, only child's age (children aged 4-year-old) was associated to a negative impact on the symptoms domain, functional limitation domain and also on total B-ECOHIS scores. This can be justified taking into consideration that the severity of oral diseases and disorders, in general, are more prevalent and cumulative as age increases. There is no consensus about the relationship between ETW and socioeconomic factors. There are studies showing no association between ETW and socioeconomic factors in the different dentitions ${ }^{6,11}$. Conversely, some studies have shown association between ETW and high socioeconomic status ${ }^{9,36}$, however higher prevalence of ETW in lower socioeconomic status has also been documented ${ }^{10}$. On the other hand, our multivariate adjusted model indicates that families who had 2 or more children in the house have a significant negative impact on the self-image/social interaction domain, however, this association was only observed for this domain, but not for total B-ECOHIS scores.

Some potential limitations of this study should be taken into account. First, no cause-effect relationship can be deduced from a cross sectional design study such as this one. Despite its limitation, this is the first population study to investigate the impact of erosive tooth wear (ETW) on the OHRQoL of preschool children. In addition, a relatively good representative sample of the population was selected. Biological, socioeconomic and behavior features are also risk factors for ETW, however these factors are rarely investigated simultaneously in epidemiological surveys. Moreover, our study would have benefited from a more balanced severity of ETW in the sample since we most of the lesions in our sample were restricted to enamel. Thus, a negative impact on OHRQoL could be observed in severe lesions.

Further studies are needed in order to confirm findings of this study in populations with severe ETW. It is relevant to consider that prevalence of ETW have increased in children. Therefore, it is important to recognize the determinants directly related to ETW before the adoption of strategies for its prevention.

\section{CONCLUSION}

In conclusion, ETW did not affect the OHRQoL in this sample of Brazilian preschool children. 
G TELLO, LB OLIVEIRA, C MURAKAMI, GC BONINI, J ABANTO and M BÖNECKER participated in the design, organization and writing of the paper.

\section{ACKNOWLEDGMENTS}

This study was financially supported by the Fundação de Amparo a Pesquisa do Estado de São Paulo (FAPESP), process numbers: 2011/18412-8, 2012/00944$6,2013 / 10330-8$. The authors also thank the local

2. Murakami C, Tello G, Abanto J, Oliveira LB, Bonini GC, Bönecker $M$. Trends in the prevalence of erosive tooth wear in Brazilian preschool children. Int J Paediatr Dent. 2016 Jan;26(1):60-5. doi: 10.1111/ipd.12159

3. De Carvalho Sales-Peres SH, De Carvalho Sales-Peres A, Marsicano JA, De Moura-Grec PG, De Carvalho CA, De Freitas AR, et al. An epidemiological scoring system for tooth wear and erosive wear. Int Dent J. 2013 Jun;63(3):154-60. doi: 10.1111/idj.12026

4. Nahás Pires Corrêa MS, Nahás Pires Corrêa F, Nahás Pires Corrêa JP, Murakami C, Mendes FM. Prevalence and associated factors of dental erosion in children and adolescents of a private dental practice. Int J Paediatr Dent. 2011 Nov;21(6):451-8. doi: 10.1111/j.1365-263X.2011.01150.x

5. Kreulen C, Van 't Spijker A, Rodriguez J, Bronkhorst E, Creugers $N$, Bartlett D. Systematic review of the prevalence of tooth wear in children and adolescents. Caries Res. 2010;44(2):151-9. doi: $10.1159 / 000308567$

6. Murakami C, Oliveira LB, Sheiham A, Corrêa MSNP, Haddad $A E$, Bönecker $M$. Risk indicators for erosive tooth wear in brazilian preschool children. Caries Res. 2011;45(2):121-9. doi: $10.1159 / 000324807$

7. Li H, Zou Y, Ding G. Dietary factors associated with dental erosion: a meta-analysis. PLoS One. 2012;7(8):e42626. doi: 10.1371/journal.pone.0042626

8. Abu-Ghazaleh SB, Burnside G, Milosevic A. The prevalence and associated risk factors for tooth wear and dental erosion in 15- to 16-year-old schoolchildren in Amman, Jordan. Eur Arch Paediatr Dent. 2013 Feb;14(1):21-7. doi: 10.1007/s40368-012-0006-3

9. Mangueira DF, Sampaio FC, Oliveira AF. Association between socioeconomic factors and dental erosion in brazilian schoolchildren. J Public Health Dent. 2009;69(4):254-9. doi: 10.1111/j.1752-7325.2009.00131.x

10. Kazoullis S, Seow WK, Holcombe T, Newman B, Ford D. Common dental conditions associated with dental erosion in schoolchildren in Australia. Pediatr Dent. 2007 Jan-Feb;29(2):33-9.

11. Vargas-Ferreira F, Praetzel JR, Ardenghi TM. Prevalence of tooth erosion and associated factors in 11-14-year-old Brazilian schoolchildren. J Public Health Dent. 2011;71(1):6-12. doi: 10.1111/j.1752-7325.2010.00194.x

12. Abanto J, Carvalho TS, Mendes FM, Wanderley MT, Bönecker M, authorities (Health Council) Secretaria Municipal de Saúde of Diadema, the dental examiners, dental nurses, auxiliary nurses, community agents, and the children and their families for their cooperation in carrying out this study.

\section{REFERENCES}

1. Lussi A, Carvalho TS. Erosive tooth wear: a multifactorial condition of growing concern and increasing knowledge. Monogr Oral Sci. 2014;25:1-15. doi: 10.1159/000360380

Raggio DP. Impact of oral diseases and disorders on oral healthrelated quality of life of preschool children. Community Dent Oral Epidemiol. 2011 Apr;39(2):105-14. doi: 10.1111/j.16000528.2010.00580.x

13. Vargas-Ferreira F, Piovesan C, Praetzel JR, Mendes FM, Allison PJ, Ardenghi TM. Tooth erosion with low severity does not impact child oral health-related quality of life. Caries Res. 2010;44(6):531-39. doi: 10.1159/000321447

14. Kirkwood BR, Sterne JAC. Essential medical statistics. Oxford: Blackwell Science; 2003.

15. Instituto Brasileiro de Geografia e Estatística [citado 2016 Nov 10]. Disponível em: <https://www.ibge.gov.br>.

16. O'Brien M. Children's dental health in the United Kingdom, 1993; in., London: Her Majesty's Stationery Office, 1994

17. Al-Malik Ml, Holt R, Bedi R. The relationship between erosion, caries and rampant caries and dietary habits in preschool children in Saudi Arabia. Int J Paediatr Dent. 2001 Nov;11(6):430-9.

18. Al-Majed I, Maguire A, Murray JJ. Risk factors for dental erosion in 5-6 year old and 12-14 year old boys in Saudi Arabia. Community Dent Oral Epidemiol. 2002 Feb;30(1):38-46.

19. Chadwick B, Pendry L. Children's dental health in the United Kingdom 2003: non-carious dental conditions. London: Office for National Statistics; 2004.

20. Hinds K, Gregory J. National diet and nutrition survey: children aged $1 \frac{1}{2}$ to $4 \frac{1}{2}$ years. London: Her Majesty's Stationery Office; 1995.

21. Jones SG, Nunn JH. The dental health of 3-year-old children in east cumbria 1993. Community Dent Health. 1995 Sep;12(3):161-6.

22. Ganss C, Klimek J, Giese K. Dental erosion in children and adolescents-a cross-sectional and longitudinal investigation using study models. Community Dent Oral Epidemiol. 2001 Aug;29(4):264-71.

23. Millward A, Shaw L, Smith AJ, Rippin JW, Harrington E. The distribution and severity of tooth wear and the relationship between erosion and dietary constituents in a group of children. Int J Paediatr Dent. 1994b Sep;4(3):151-7.

24. WHO. Oral Health Surveys. Basic methods. $5^{\text {th }}$ ed. Geneva: World Health Organization; 2013. 
25. Knutson JW. An index of the prevalence of dental caries in school children. Public Health Rep. 1944;54:253-63.

26. Glendor U, Halling A, Andersson L, Eilert-Petersson E. Incidence of traumatic dental injuries in children and adolescents in the county of Västmanland. Swed Dent J. 1996;20(1-2):15-28.

27. Kramer PF, Feldens CA, Ferreira SH, Bervian J, Rodrigues $\mathrm{PH}$, Peres MA. Exploring the impact of oral diseases and disorders on quality of life of preschool children. Community Dent Oral Epidemiol. 2013;41(4):327-35. doi: 10.1111/cdoe.12035

28. Abanto J, Tello G, Bonini GC, Oliveira LB, Murakami C, Bönecker $M$. Impact of traumatic dental injuries and malocclusions on quality of life of preschool children: a population-based study. Int J Paediatr Dent. 2015; 25(1):18-28. doi: 10.1111/ipd.12092

29. Scarpelli AC, Oliveira BH, Tesch FC, Leão AT, Pordeus IA, Paiva SM. Psychometric properties of the Brazilian version of the Early Childhood Oral Health Impact Scale (B-ECOHIS). BMC Oral Health. 2011;11:19. doi: 10.1186/1472-6831-11-19.

30. Bönecker M, Abanto J, Tello G, Oliveira LB. Impact of dental caries on preschool children's quality of life: an update. Braz Oral Res. 2012;26(Suppl 1):103-7.

31. Moimaz S, Araújo P, Chiba F, Garbín C, Saliba N. Prevalence of deciduous tooth erosion in childhood. Int J Dent Hyg. 2013 Aug;11(3):226-30. doi: 10.1111/idh.12020
32. Walker A, Gregory J, Bradnock G, Nunn JH, White D. National diet and nutrition survey: Young people aged 4-18 years. London: Her Majesty's Stationery Office; 2000

33. MMS Salas, RVF Dantas, HR Sarmento, Vargas-Ferreira F, Torriani D, Demarco FF. Tooth erosion and dental caries in schoolchildren: is there a relationship between them? Braz J Oral Sci. 2014;13(1):12-16. doi: 10.1111/j.1365-263X.2011.01170.x.

34. Feferbaum R, de Abreu LC, Leone C. Fluid intake patterns: an epidemiological study among children and adolescents in Brazil. BMC Public Health. 2012 Nov;12:1005. doi: 10.1186/14712458-12-1005.

35. Brazil, Ministry of Health. II Research of Breastfeeding Predominance in Brazilian Capitals and Federal District. Brasília-DF, 2009. Avaliable at: http://bvsms.saude.gov.br/bvs/ publicacoes/pesquisa_prevalencia_aleitamento_materno.pdf

36. Peres KG, Armênio MF, Peres MA, Traebert J, De Lacerda JA. Dental erosion in 12-year-old schoolchildren: a cross-sectional study in Southern Brazil. Int Dent J. 2005 Jul;15(4):249-55.

Received on: 30/6/2017

Final version resubmitted on: 23/8/2017

Approved on: 20/9/2017 